\title{
Effect of using trace minerals (copper, zinc, selenium, and manganese) and vitamins $A$ and $E$ on the metabolic profile of Holstein cows in the transition period
}

\section{Efeito do uso de minerais traços (cobre, zinco, selênio e manganês) e vitaminas A e $\mathbf{E}$ sobre o perfil metabólico de vacas holandesas no período de transição}

\author{
Silvana Giacomini Collet ${ }^{1 *}$; Rejane Dos Santos Sousa ${ }^{2}$; Enrico Lippi Ortolani ${ }^{3}$; \\ André Thaler Neto ${ }^{4}$; Michèli Cristina Carpeggiani ${ }^{5}$; Thais Caroline Ferronatto ${ }^{5}$; \\ Gustavo Vinícius Taffarel ${ }^{5}$; Mateus Alan Demeda ${ }^{5}$; Marta Lizandra do Rego Leal ${ }^{6}$
}

\begin{abstract}
The aim of this study was to assess the metaphylactic effect of subcutaneous doses of trace minerals (copper, zinc, selenium, and manganese) and vitamins A and $\mathrm{E}$ on biochemical (NEFA, BHBA, fructosamine, urea, triglycerides, HDL, and calcium) and hormonal parameters (cortisol, insulin, and IGF-1) of Holstein cows in the transition period. Sixty animals kept in a semi-confinement system, with an average production of 22 liters of milk per day (Farm 1) and 24 liters of milk per day (Farm 2) and a diet according to NRC (2001) with a low metabolic challenge, were divided into two groups: a treatment group, supplemented with trace minerals and vitamins (MTVG) $(n=30)$, and a control group $(\mathrm{CG})(\mathrm{n}=30)$. The collection of blood samples was performed at the moments M1 (21 days prepartum), M2 (14 days prepartum), M3 (7 days prepartum), M4 (parturition day), M5 (7 days postpartum), M6 (14 days postpartum), and M7 (21 days postpartum). The experimental design was a randomized block design and the data were submitted to analysis of variance with repeated measures in time within the random variable cow. Differences were considered significant at $5 \%$ significance level and trend at $10 \%$ level. No difference was observed between treatment and the interaction treatment $\times$ day in the assessed parameters. However, some variables showed a significant difference of day. NEFA levels $(\mathrm{P}<0.0001)$ were higher on the parturition day. BHBA concentrations were higher after parturition $(\mathrm{P}=0.0031)$, with a peak at the third week of lactation. Fructosamine showed increasing values until the parturition day $(\mathrm{P}=0.0373)$, in which higher concentrations were observed. Average values of HDL were higher at 21 days postpartum $(\mathrm{P}<0.0001)$. Triglycerides levels remained high during the prepartum period but showed a sudden drop on the parturition day $(\mathrm{P}<0.0001)$, with lower values postpartum. Regarding serum calcium and IGF-1, lower values were observed on the parturition day $(\mathrm{P}<0.001)$ for both parameters. Cortisol presented a difference regarding day, with higher values on the parturition day $(\mathrm{P}=0.0151)$. Thus, the use of trace minerals and vitamins $\mathrm{A}$ and $\mathrm{E}$ in animals with an adequate body score and low metabolic challenge presents a low response to biochemical and hormonal parameters.

Key words: Metabolism. Trace minerals. Transition period. Dairy cows. Vitamins.
\end{abstract}

1 Discente, Universidade Federal de Santa Maria, UFSM, Santa Maria, RS, Brasil. E-mail: silvana.collet@unoesc.edu.br

2 Discente, Universidade de São Paulo, USP, São Paulo, SP, Brasil. E-mail: rejane.santossousa@gmail.com

Prof., USP, São Paulo, SP, Brasil. E-mail: ortolani@usp.br

4 Profs., Universidade do Estado de Santa Catarina, UDESC, Lages, SC, Brasil. E-mail: andre.thaler@udesc.br

5 Discentes, Universidade do Oeste de Santa Catarina, UNOESC, Xanxerê, SC, Brasil. E-mail: mi_jba@hotmail.com; thaisferronatto@hotmail.com; gustavo.taffarel@yahoo.com.br; mateus_demeda@hotmail.com

6 Prof ${ }^{a}$, UFSM, Santa Maria, RS, Brasil. E-mail: martalizandra@gmail.com

Author for correspondence 


\section{Resumo}

O objetivo desse estudo foi avaliar o efeito metafilático de doses subcutâneas de minerais traços (cobre, zinco, selênio e manganês) e vitaminas A e E, sobre parâmetros bioquímicos (teores de AGNES, BHBA, frutosamina, ureia, triglicerídos, HDL e cálcio) e hormonais (cortisol, insulina e IGF-1) de vacas holandesas no período de transição. Sessenta animais, provenientes de duas propriedades com sistema de semi-confinamento, com médias de produção de 22 litros de leite por dia (propriedade 1) e 24 litros de leite por dia (propriedade 2), recebendo dieta de acordo a recomendação do NRC (2001), ou seja, em baixo desafio metabólico, foram divididos em dois grupos: animais que receberam doses de minerais traços e vitaminas (GMTV) $(n=30)$ e Controle $(\mathrm{GC})(\mathrm{n}=30)$. As coletas das amostras de sangue foram realizadas nos seguintes momentos: M1 (21 dias pré-parto), M2 (14 dias pré-parto), M3 (sete dias pré-parto), M4 (dia do parto), M5 (sete dias após o parto), M6 (14 dias após o parto) e M7 (21 dias após o parto). O delineamento experimental foi em blocos casualizados, sendo os dados submetidos à análise de variância, com medidas repetidas no tempo dentro da variável aleatória vaca. Foram consideradas significativas as diferenças ao nível de $5 \%$ de significância e tendência ao nível de $10 \%$. Não houve diferença entre tratamento e interação tratamento x dia nos parâmetros avaliados. No entanto, para algumas variáveis houve diferença significativa de dia. Os teores de AGNES ( $\mathrm{P}<$ $0,0001)$ foram maiores no dia do parto. As concentrações de BHBA $(\mathrm{P}=0,0031)$ alcançaram os valores mais elevados na terceira semana de lactação. A frutosamina exibiu valores crescentes até o dia do parto $(\mathrm{P}=0,0373)$, onde se observaram maiores concentrações. Os valores médios de HDL foram mais elevados 21 dias após o parto $(\mathrm{P}<0,0001)$, e os teores de triglicerídeos mantiveram-se com valores altos no período pré-parto, porém apresentaram queda brusca no dia do parto $(\mathrm{P}<0,0001)$, mantendo valores mais baixos após o parto. Quanto ao cálcio sérico e ao IGF-1 observaram-se menores valores no dia do parto $(\mathrm{P}<0,001)$. O cortisol apresentou diferença de dia com valores mais elevados no dia do parto $(\mathrm{P}=0,0151)$. Pode-se observar nesse estudo, que o uso de minerais traços e vitaminas $\mathrm{A}$ e $\mathrm{E}$ em animais com adequado escore corporal e com pouco desafio metabólico, apresenta pouca resposta aos parâmetros bioquímicos e hormonais.

Palavras-chave: Metabolismo. Minerais traços. Período de transição. Vacas leiteiras. Vitaminas.

\section{Introduction}

The transition period for dairy cows comprises three weeks before and after parturition, an important time in which physiological, metabolic, nutritional, and hormonal changes occur (INGVARTSEN; MOYES, 2012) and prepare the cow for lactation. Especially on the two days before parturition, there is a reduction in dry matter intake (DMI) (LEAN et al., 2013), which can be up to 30\% (HAYIRLI et al., 2002). The return or increase occurs slowly, not following the requirements of the cow and leading to a negative energy balance (NEB) (ALVES et al., 2009) and, consequently, to oxidative stress up to four to eight weeks postpartum (SORDILLO; AITKEN, 2009; KHATTI et al., 2017; PUTMAN et al., 2018).

Oxidative stress is a consequence of a reduction in the mechanisms of antioxidant protection and it is known that there is a relationship between oxidative stress and disease on dairy cows, particularly during the transition period (SORDILLO; AITKEN, 2009) due to the high metabolic challenge caused by a reduction in DMI, increase of milk production, and negative energy balance (NEB). In this period, there is also a reduction in the concentrations of vitamins and minerals that act as cofactors of some enzymes of the antioxidant system, such as the enzyme SOD and GPx, as well as non-enzymatic systems, which are linked to immunity (XIN et al., 1993).

In the literature, few studies assess the use of trace minerals and vitamins and their effect on metabolic parameters (AVCI; KIZIL, 2013; OMUR et al., 2016). Thus, this study aimed to assess the metaphylactic effect of subcutaneous doses of a multimineral and multivitamin containing copper $(\mathrm{Cu})$, zinc $(\mathrm{Zn})$, selenium $(\mathrm{Se})$, manganese $(\mathrm{Mn})$, 
and vitamins $\mathrm{A}$ and $\mathrm{E}$ on biochemical and hormonal parameters of dairy cows in the transition period.

\section{Material and Methods}

The experimental protocol was approved by the Ethics Committee on Animal Use of the Federal University of Santa Maria (CEUA/UFSM) (4688090815). This study was carried out between March and October 2016 in two commercial farms located in Xanxerê (Farm 1) and Faxinal dos Guedes (Farm 2), SC, with a semi-confinement system. Farm 1 housed 46 lactating animals with an average weight of $630 \mathrm{~kg}$ and an average production of 22 liters of milk per day, while Farm 2 housed 34 lactating animals with an average weight of 580 $\mathrm{kg}$ and an average production of 24 liters of milk per day. Food management was similar in both properties. In the period between 60 and 30 days before parturition, the animals fed roughage (African Star pasture, Cynodon spp.) and commercial mineral concentrate. In the prepartum period (30 days before parturition), the animals fed roughage (corn silage) and commercial anionic concentrate. In the lactation period, the cows fed roughage (corn silage and pasture of oat and ryegrass or Tifton 85, Cynodon spp.) and concentrate. The average score of body condition of animals was maintained at all moments between 3.0 and 3.5, according to the scale of 1 to 5 (EDMONSON et al., 1989). The chemical composition of the diet at each farm and the National Research Council (NRC, 2001) recommendation are shown in Tables 1 and 2.

Table 1. National Research Council (NRC, 2001) recommendation for diets of dry and lactating cows and chemical composition of the total diet at prepartum and lactation periods in the Farm 1.

\begin{tabular}{|c|c|c|c|c|c|c|c|c|}
\hline & Diet $1^{1}$ & Diet $1 \mathrm{a}^{2}$ & Diet $1 b^{3}$ & Diet $2^{4}$ & Diet $2^{5}$ & Diet $3^{6}$ & $\operatorname{Diet} 3 \mathrm{a}^{7}$ & Diet $3 b^{8}$ \\
\hline $\mathrm{CM}(\%)$ & 30 & 19.3 & 18.4 & 18.4 & 32.2 & 35 & 36.3 & 29.3 \\
\hline CP (\%) & 12 & 14.5 & 11 & 12 & 11.1 & 15 & 13.5 & 16.6 \\
\hline NDF (\%) & 33 & 29.1 & 66 & 33 & 42 & 33 & 37.4 & 37 \\
\hline $\mathrm{ADF}(\%)$ & 21 & 61.3 & 24.5 & 21 & 26.1 & 21 & 20.9 & 21 \\
\hline TDN (\%) & 51 & 55 & 55.3 & 51 & 69.6 & 66 & 68.9 & 73.5 \\
\hline NFC (\%) & Max.42 & 17.5 & 6.1 & Max.42 & 49 & 37 & 39.7 & 39.5 \\
\hline Starch (\%) & Max.25 & 7.6 & 1.0 & Max.25 & 26 & 27 & 29.3 & 28 \\
\hline Lipid (\%) & . & 2.1 & 2.6 & . & 2.6 & 3.5 & 2.4 & 2.6 \\
\hline $\mathrm{Cu}(\mathrm{mg} / \mathrm{kg})$ & 18 & 8 & 1 & 18 & 21 & 18 & 19 & 20 \\
\hline $\mathrm{Zn}(\mathrm{mg} / \mathrm{kg})$ & 43 & 65 & 1 & 43 & 26 & 43 & 28 & 35 \\
\hline $\mathrm{Se}(\mathrm{mg} / \mathrm{kg})$ & 0.3 & 0.5 & 0.01 & 0.3 & 0.66 & 0.3 & 0.56 & 57 \\
\hline $\mathrm{Mn}(\mathrm{mg} / \mathrm{kg})$ & 14 & 88 & 2 & 14 & 63 & 14 & 51 & 51 \\
\hline
\end{tabular}

${ }^{1} \mathrm{NRC}$ (2001) recommendation for a diet at 60 to 30 days before parturition. ${ }^{2}$ Diet at 60 to 30 days before parturition offered in the summer. ${ }^{3}$ Diet at 60 to 30 days before parturition offered in the winter. ${ }^{4} \mathrm{NRC}$ (2001) recommendation for a diet at 30 days before parturition. ${ }^{5}$ Diet at 30 days before parturition offered in the summer and winter. ${ }^{6} \mathrm{NRC}(2001)$ recommendation for a lactation diet (cows with an average weight of $630 \mathrm{~kg}$ and producing 22 liters of milk per day). ${ }^{7}$ Lactation diet offered in the summer. ${ }^{8} \mathrm{Lactation}$ diet offered in the winter.

The animals were randomly divided into two groups: animals receiving trace minerals and injectable vitamins A and E (MTVG) $(\mathrm{n}=30)$ and control group $(\mathrm{CG})(\mathrm{n}=30)$, with 22 animals from Farm 1 and 38 animals from Farm 2. The administration of minerals and vitamins was performed subcutaneously with $5 \mathrm{~mL}$ of product containing $10 \mathrm{mg} / \mathrm{mL}$ copper (as edetate), $40 \mathrm{mg}$ / 
$\mathrm{mL}$ zinc (as edetate), $10 \mathrm{mg} / \mathrm{mL}$ manganese (as edetate), and $5 \mathrm{mg} / \mathrm{mL}$ selenium (as sodium selenite) (Adapter ${ }^{\circledR} \min$, copper, zinc, selenium, manganese, Biogenesis Bagó, Argentina) and $5 \mathrm{~mL}$ of product containing $35 \mathrm{mg} / \mathrm{mL}$ vitamin A (as palmitate) and $50 \mathrm{mg} / \mathrm{mL}$ vitamin $\mathrm{E}$ (as acetate) (Adaptador ${ }^{\circledR}$ vit, vitamin A, vitamin E, Biogenesis Bagó, Argentina). Minerals and vitamins were administered at 225 and 265 days of gestation and on the parturition day. Animal from CG received subcutaneous injections of $5 \mathrm{~mL} 0.9 \%$ sodium chloride at the same periods. Blood samples were collected at the following moments: M1 (21 days prepartum), M2 (14 days prepartum), M3 (7 days prepartum), M4 (parturition day), M5 (7 after postpartum), M6 (14 days postpartum), and M7 (21 days postpartum).

Table 2. National Research Council (NRC, 2001) recommendation for diets of dry and lactating cows and chemical composition of the total diet at prepartum and lactation periods in the Farm 2.

\begin{tabular}{|c|c|c|c|c|c|c|c|c|}
\hline & Diet $1^{1}$ & Diet $1 \mathrm{a}^{2}$ & Diet $1 b^{3}$ & Diet $2^{4}$ & Diet $2^{5}$ & Diet $3^{6}$ & Diet $3 a^{7}$ & Diet $3 b^{8}$ \\
\hline DM (\%) & 30 & 18.4 & 22 & 18.4 & 32.4 & 32 & 32.8 & 26 \\
\hline CP (\%) & 12 & 17.7 & 11.3 & 12 & 15.4 & 16 & 14.3 & 16.4 \\
\hline NDF (\%) & 33 & 67.2 & 68 & 33 & 53.5 & 32 & 46 & 38.3 \\
\hline $\mathrm{ADF}(\%)$ & 21 & 37 & 27 & 21 & 27 & 21 & 24.8 & 19.8 \\
\hline TDN (\%) & 51 & 58.5 & 57.3 & 51 & 66.7 & 72 & 69.3 & 70.4 \\
\hline NFC (\%) & Max.42 & 10.7 & 6 & Max.42 & 25.9 & 38 & 34.3 & 39.8 \\
\hline Starch $(\%)$ & Max.25 & 3.9 & 1 & Max. 25 & 18 & 28.5 & 25 & 25.5 \\
\hline Lipid (\%) & . & 1.8 & 2.4 & . & 2.1 & 3.5 & 2.3 & 2.7 \\
\hline $\mathrm{Cu}(\mathrm{mg} / \mathrm{kg})$ & 18 & 39 & 21 & 18 & 12 & 18 & 13 & 13 \\
\hline $\mathrm{Zn}(\mathrm{mg} / \mathrm{kg})$ & 43 & 34 & 9 & 43 & 0.61 & 43 & 68 & 79 \\
\hline $\mathrm{Se}(\mathrm{mg} / \mathrm{kg})$ & 0.3 & 0.56 & 0.58 & 0.3 & 0.69 & 0.3 & 0.51 & 0.53 \\
\hline Mn (mg/kg) & 14 & 78 & 1 & 14 & 31 & 14 & 27 & 50 \\
\hline
\end{tabular}

${ }^{1} \mathrm{NRC}$ (2001) recommendation for a diet at 60 to 30 days before parturition. ${ }^{2}$ Diet at 60 to 30 days before parturition offered in the summer. ${ }^{3}$ Diet at 60 to 30 days before parturition offered in the winter. ${ }^{4} \mathrm{NRC}$ (2001) recommendation for a diet at 30 days before parturition. ${ }^{5}$ Diet at 30 days before parturition offered in the summer and winter. ${ }^{6} \mathrm{NRC}(2001)$ recommendation for a lactation diet (cows with an average weight of $580 \mathrm{~kg}$ and producing 24 liters of milk per day). ${ }^{7}$ Lactation diet offered in the summer. ${ }^{8} \mathrm{Lactation}$ diet offered in the winter.

Blood samples were collected by puncturing the coccygeal vein using the vacutainer system in a tube without anticoagulant. After collection, blood was centrifuged for 10 minutes at $447 \mathrm{x} g$ to obtain serum, which was frozen at $-20{ }^{\circ} \mathrm{C}$ in Eppendorftype tubes until the time of analyses. Serum samples were used to determine the non-esterified fatty acids (NEFA), beta-hydroxybutyrate (BHBA), high-density lipoproteins (HDL), triglycerides, fructosamine, urea, calcium, insulin, cortisol, and insulin-like growth factor-1 (IGF-1). NEFA and BHBA contents were measured in a Randox ${ }^{\circledR}$ automatic biochemical analyzer using commercial Randox $^{\circledR}$ kits. Analyses of HDL, triglycerides, fructosamine, calcium, and urea were performed in a Labmax $^{\circledR}$ Labtest $^{\circledR}$ automatic biochemical analyzer using commercial Labtest ${ }^{\circledR}$ kits. Hormone determinations (insulin, IGF-1, and cortisol) were performed by chemiluminescent assay using a commercial Siemens kit in an Immulite $1000^{\circledR}$ immunoassay analyzer (Siemens).

The experimental design was a randomized block design with treatments formed by a group of 
animals that received injectable trace minerals and vitamins $\mathrm{A}$ and $\mathrm{E}$ and a control group. The data were submitted to analysis of variance with measures repeated in time within the random variable cow. The analyses were performed using the procedure MIXED of the statistical package SAS, with an autoregressive covariance structure based on the Akaike information criterion (AIC). The statistical model includes the explanatory variables treatment, day in relation to parturition ( -21 to +21 days), the interaction treatment $\times$ day, and parity. The data were previously tested for normality of residuals by the Shapiro-Wilk test. Differences were considered significant at 5\% significance level and trend at 10\% level.

\section{Results and Discussion}

The data regarding NEFA contents are shown in Table 3 and Figure 1a. No difference was observed between treatments for NEFA values $(\mathrm{P}=0.3052)$, but higher values of this metabolite were observed on the parturition day in MTVG and CG $(\mathrm{P}<0.0001)$. Ramos et al. (2012) also observed no effect of trace minerals supplementation on the plasma concentrations of NEFA in cows in the transition period. Silva Filho et al. (2017) observed a similar behavior of serum values of NEFA during the transition period in dairy cows. Sordillo and Raphael (2013) reported that plasma concentrations of NEFA increased dramatically on the parturition day, with a reduction in serum concentrations after parturition. A similar behavior was observed in this study for MTVG and CG (Figure 1a).

Table 3. Means of minimum squares \pm standard error of the mean (SE) and $\mathrm{P}$ value for beta-hydroxybutyrate (BHBA), non-esterified fatty acids (NEFA), fructosamine, high-density lipoprotein (HDL), triglycerides, urea, calcium, cortisol, insulin, and insulin-like growth factor-1 (IGF-1) in Holstein cows supplemented with injectable trace minerals and vitamins A and E (MTVG) or control.

\begin{tabular}{|c|c|c|c|c|c|}
\hline Variable & Group & Mean and SE & $\mathbf{P}_{\text {Treatment }}$ & $\boldsymbol{P}_{D a v}$ & $\boldsymbol{P}_{\text {Treatment*Dav }}$ \\
\hline \multirow{2}{*}{ NEFA (mmol/L) } & MTVG & $0.32 \pm 0.033$ & \multirow{2}{*}{0.3052} & \multirow{2}{*}{$<0.0001$} & \multirow{2}{*}{0.5321} \\
\hline & Control & $0.28 \pm 0.27$ & & & \\
\hline \multirow{2}{*}{$\mathrm{BHBA}(\mathrm{mmol} / \mathrm{L})$} & MTVG & $0.70 \pm 0.035$ & \multirow{2}{*}{0.7270} & \multirow{2}{*}{0.0031} & \multirow{2}{*}{0.8349} \\
\hline & Control & $0.68 \pm 0.030$ & & & \\
\hline \multirow{2}{*}{ Fructosamine $(\mu \mathrm{mol} / \mathrm{L})$} & MTVG & $227.61 \pm 3.08$ & \multirow{2}{*}{0.7866} & \multirow{2}{*}{0.0373} & \multirow{2}{*}{0.9451} \\
\hline & Control & $228.69 \pm 2.64$ & & & \\
\hline \multirow{2}{*}{$\operatorname{HDL}(\mathrm{mg} / \mathrm{dL})$} & MTVG & $1.61 \pm 0.08$ & \multirow{2}{*}{0.9385} & \multirow{2}{*}{$<0.0001$} & \multirow{2}{*}{0.5904} \\
\hline & Control & $1.61 \pm 0.07$ & & & \\
\hline \multirow{2}{*}{ Triglycerides (mg/dL) } & MTVG & $16.26 \pm 0.60$ & \multirow{2}{*}{0.8093} & \multirow{2}{*}{$<0.0001$} & \multirow{2}{*}{0.3212} \\
\hline & Control & $16.07 \pm 0.51 \mathrm{~A}$ & & & \\
\hline \multirow{2}{*}{ Urea (mg/dL) } & MTVG & $33.51 \pm 1.60$ & \multirow{2}{*}{0.6842} & \multirow{2}{*}{0.4442} & \multirow{2}{*}{0.7824} \\
\hline & Control & $32.65 \pm 1.36$ & & & \\
\hline \multirow[t]{2}{*}{ Calcium (mg/dL) } & MTVG & $9.40 \pm 0.083$ & \multirow{2}{*}{0.2657} & \multirow{2}{*}{$<0.0001$} & \multirow{2}{*}{0.2055} \\
\hline & Control & $9.54 \pm 0.09$ & & & \\
\hline \multirow[t]{2}{*}{ Cortisol ( $\mu \mathrm{g} / \mathrm{dL})$} & MTVG & $1.44 \pm 0.12$ & \multirow{2}{*}{0.9169} & \multirow{2}{*}{0.0151} & \multirow{2}{*}{0.8070} \\
\hline & Control & $1.46 \pm 0.11$ & & & \\
\hline \multirow{2}{*}{ Insulin $(\mu \mathrm{IU} / \mathrm{mL})$} & MTVG & $13.48 \pm 2.58$ & \multirow{2}{*}{0.8730} & \multirow{2}{*}{0.1172} & \multirow{2}{*}{0.7678} \\
\hline & Control & $12.95 \pm 2.19$ & & & \\
\hline IGF $1 / \mathrm{no} / \mathrm{mI})$ & MTVG & $61.76 \pm 4.86$ & 02243 & $<0001$ & 00658 \\
\hline & Control & $69.61 \pm 4.27$ & & & \\
\hline
\end{tabular}


According to Leblanc et al. (2005) and Ospina et al. (2010), NEFA concentrations up to $0.50 \mathrm{mmol} / \mathrm{L}$ are acceptable. However, higher values are associated with an increased risk of metabolic diseases. The average values found in all experimental periods and animals of both groups were lower than $0.50 \mathrm{mmol} / \mathrm{L}$. In the study by Avci and Kizil (2013), cows that received subcutaneous injections of trace minerals during the transition period had a decrease in NEFA contents. Omur et al. (2016) used trace minerals and vitamins A, D, and E in cows in the transition period and observed higher NEFA values in the control group. They suggested that trace minerals combined with vitamins possibly affect lipomobilization and negative energy balance.
No difference was observed in BHBA values between MTVG and CG $(\mathrm{P}=0.7270)$. However, higher BHBA values were detected in the third week postpartum $(\mathrm{P}=0.0031)$ in both groups (Table 3 and Figure $1 b$ ). In studies carried out by Pickett et al. (2003) and Mecitoğlu et al. (2017), BHBA concentration also increased after parturition, peaking at the third week of lactation. Cows in which glucose demand exceeds liver glycogen capacity typically have BHBA increases 3 to 6 weeks postpartum (CHAPINAL et al., 2011), a fact related to the postpartum NEB.

Figure 1. Average values of biochemical parameters of Holstein cows in the transition period as a function of lactating weeks in females from MTVG (- - ) or CG (-).

a)

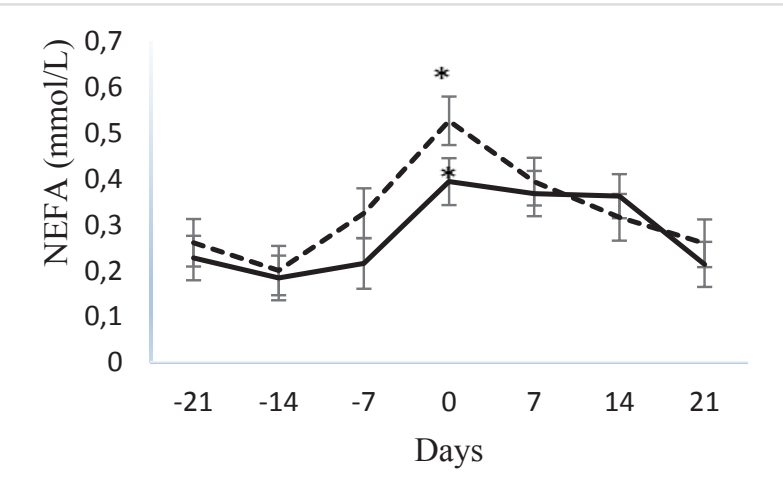

c)

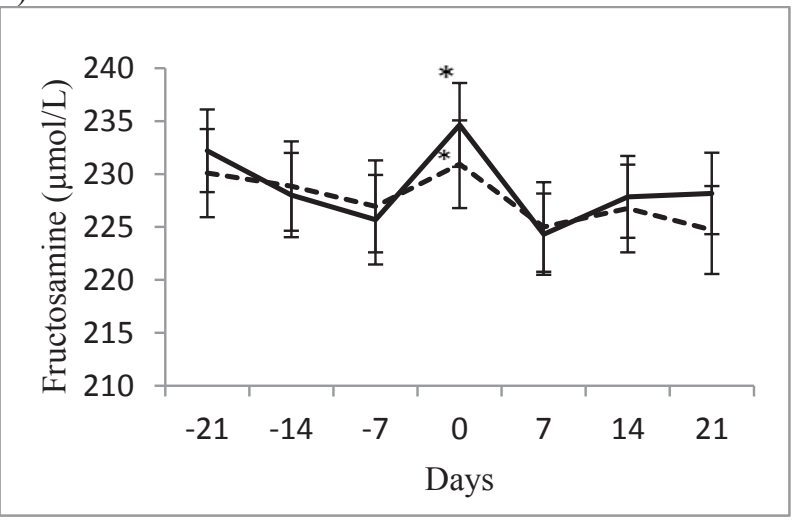

b)

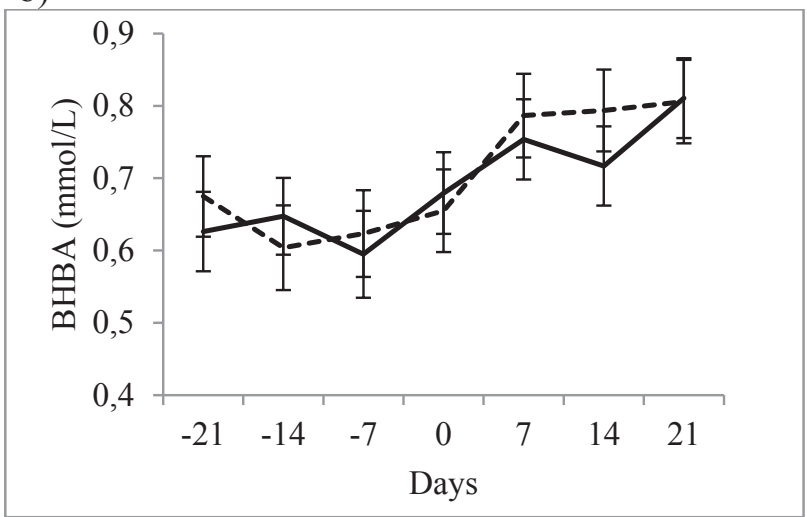

d)

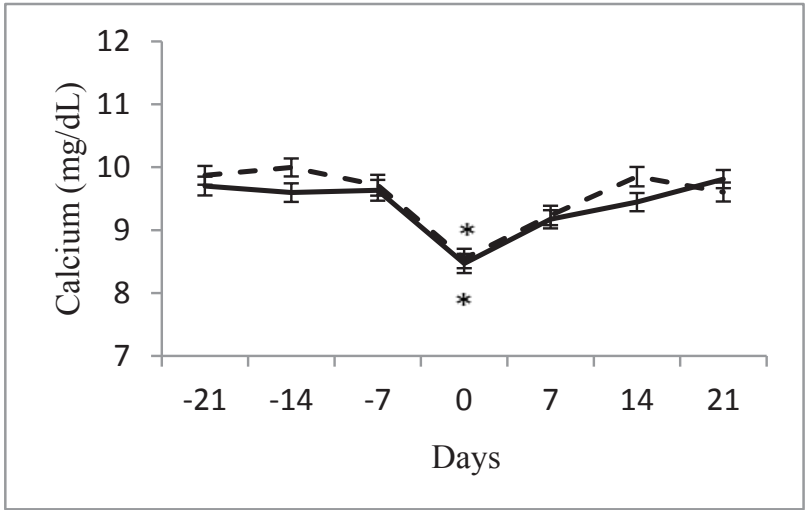


continuation

e)

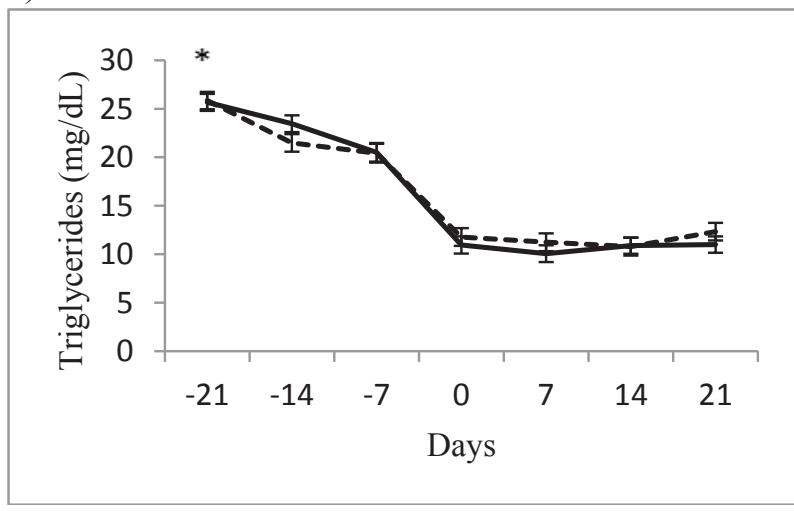

Omur et al. (2016) used trace minerals and vitamins $\mathrm{A}, \mathrm{D}$, and $\mathrm{E}$ in cows in the transition period and observed lower BHBA values in the group of treated cows when compared to those in the control group. Machado et al. (2014) observed a trend of lower BHBA concentrations in cows receiving injectable trace minerals $(\mathrm{Cu}, \mathrm{Zn}$, Se, and $\mathrm{Mn})$, but only in cows above the third parturition and with a high production level. There is no clarity to explain how the supplementation with trace minerals and vitamins decreases BHBA concentration. These authors suggest that increased BHBA values are associated with oxidative stress, an event that can be observed in animals with a high body score at parturition and is related to the metabolic state of the animal.

The results of fructosamine, HDL, and triglycerides are shown in Table 3 and Figure 1. Only a significant effect of day was observed for these parameters $(\mathrm{P}=0.0373, \mathrm{P}<0.0001$, and $\mathrm{P}<0.0001$, respectively). Fructosamine presented increasing values in both groups until the parturition day (higher value), with a reduction in the subsequent weeks (Figure 1c). Fructosamine is a glycosylated protein and a reliable parameter for the assessment of glucose metabolism because it indicates the concentration of glucose one to three weeks prior to the measures carried out in these tests (THRALL, 2007). According to Jensen et al. (1993), the normal f)

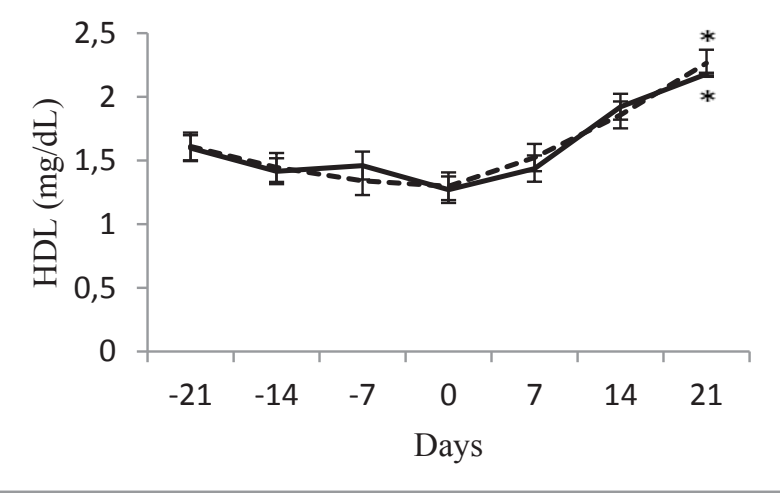

range of fructosamine for cattle is between 213 and $265 \mu \mathrm{mol} / \mathrm{L}$. The animals assessed in this study were within these limits at all experimental moments.

HDL remained low during the prepartum period and on the parturition day, with an increase 21 days postpartum, at which point a significant difference $(\mathrm{P}<0.0001)$ was observed in both $\mathrm{CG}$ and MTVG (Figure 1f). This result is similar to that observed by Ceballos et al. (2002), who verified lower values of this lipoprotein in the prepartum due to the energy requirement necessary for fetus growth and preparation of mammary gland for milk production. Omur et al. (2016) used trace minerals and vitamins $\mathrm{A}, \mathrm{D}$, and $\mathrm{E}$ in cows in the transition period at doses close to those used in our study and observed low HDL levels in treated or untreated groups, both in the prepartum and postpartum.

Triglycerides remained high during the prepartum period, but showed a sudden drop on the parturition day, maintaining lower values after parturition in both groups (Figure 1e). A similar behavior in the values of this biochemical variable was also observed in the study of Cupertino et al. (2011). Unlike our study, Avci and Kizil (2013) verified that the use of an injectable solution of selenium, copper, zinc, and manganese in dairy cows in the transition period decreased the contents of triglycerides. In this study, fructosamine concentration was high from the prepartum period to the parturition time and, 
therefore, glucose concentrations were high during this period, supplying energy demand and reducing lipomobilization. At 21 days postpartum, triglyceride concentrations increased, which is explained by Smith et al. (1997) as the lipomobilization caused by an increased in milk production, which requires a large amount of energy.

Serum calcium values are shown in Table 3 . No significant difference was observed between MTVG and CG $(\mathrm{P}=0.2657)$, but an effect of day $(\mathrm{P}<0.0001)$ could be observed (Table 3 and Figure 1d). During the prepartum period, dairy cows have a more difficult to maintain the serum calcium homeostasis, especially the fraction of ionizable calcium (ORTOLANI, 1995). According to Goff (2008), normal serum calcium values should be between 8.0 and $10.4 \mathrm{mg} / \mathrm{dL}$, with concentrations below $8.0 \mathrm{mg} / \mathrm{dL}$ being considered subclinical hypocalcemia in apparently healthy cows.

The average calcium results in both experimental groups were within the normal values for the species. However, a reduction of the serum calcium contents was observed in both groups on the parturition day, as shown in Figure 1. This decrease calcium close to parturition is frequently reported and at 12 to 24 hours after parturition, there is a lower concentration of blood calcium, since dairy cows mobilize large amounts of calcium, especially for the colostrum production (GOFF, 2008).

The average values of urea in the animals from CG and MTVG are shown in Table 3 and Figure $1 \mathrm{~g}$. No effect of treatment, day, and interaction day $x$ treatment was observed. During all the experimental moments, serum levels of this metabolic remained within the physiological for the species (GREGORY et al., 2004). Urea determination reveals information on protein metabolic activity, as well as the energy to protein ratio (LÓPEZ et al., 2004).

Omur et al. (2016) used trace minerals and vitamins $\mathrm{A}, \mathrm{D}$, and $\mathrm{E}$ in cows in the transition period and observed no change in urea values in the experimental moments (prepartum, parturition day and postpartum) in treated animals. However, the animals in the control group had a reduction in the serum values of urea at postpartum. According to these authors, the animals in the control group had this reduction in postpartum urea because of a decrease in protein anabolism.

The concentrations of the hormones insulin, IGF-1, and cortisol did not differ between MTVG and $C G(p>0.05)$ (Table 3$)$, but a significant effect of day was observed for IGF-1 $(\mathrm{P}<0.001)$ (Figure 2b) and cortisol $(\mathrm{P}=0.0151)$ (Figure $2 \mathrm{c}$ ). The hormones insulin and insulin-like growth factor-1 (IGF1) are related to the basal metabolism or nutrient deposition (CUNNINGHAM, 2004). Insulin is a hormone essentially involved in the regulation of glucose concentration in the circulation (FOULADINASHTA; CAMPBELL, 2006).

In dairy cows, the plasma concentration of insulin decreases during the dry period and remains low during the first weeks of postpartum (MOORBY et al., 2000), with acute peaks on the parturition day (KUNZ et al., 1985). In this study, no significant reduction was observed in serum insulin concentrations close to parturition in both groups (Table 3 and Figure 2a). According to Bell (1995), the low insulin concentration after parturition is associated with the resistance to this hormone in the adipose and muscular tissue to inhibit the uptake and use of glucose by them, being used essentially for milk production. The fact that there is no difference between insulin values is strictly related to the physiological contents of NEFA and BHBA observed during the experimental period, explained by the low metabolic challenge that these animals were submitted. Ramos et al. (2012) also observed no effect of trace minerals supplementation on insulin concentrations.

A significant difference of day was observed for IGF-1 $(\mathrm{P}<0.001)$ (Table 3). In addition, a reduction in IGF-1 values was observed on the parturition day in both groups (Figure 2b). Similarly, Ramos et al. (2012) observed decreased IGF-1 concentrations 
postpartum. This results in the dissociation of the somatotropic-IGF-1 axis, preventing the stimulus of IGF-1 production by hepatocytes (LUCY, 2008), initiating the process of insulin resistance for lipid mobilization for milk production (PETTERSON et al., 1993). Despite the reduced values at parturition, IGF-1 remained within the parameters considered physiological (SPICER et al., 1990) at all experimental moments in both groups. There are few studies relating IGF-1 and mineral supplementation in dairy cows. Ramos et al. (2012) also did not observe and effect of treatment when using trace minerals on this variable.

Serum contents of cortisol showed effect only of day $(\mathrm{P}=0.0151)$ (Table 3$)$, with higher values on the parturition day in MTVG and CG (Figure 2c). Other researchers have also observed a similar behavior of this hormone (NIKOLIC et al., 2003; FOSBERG, 2004; SILVA FILHO et al., 2017). Nikolic et al. (2003) also observed in the peripartum of dairy cows that high cortisol concentrations remained in the third week postpartum. Gluconeogenesis is modulated by cortisol and, during this period, a high synthesis of lactose guarantees milk production, with the need for cortisol release. In the transition period, hormonal and metabolic alterations compromise the immune system of animals (HERDT, 2000). According to Huzzey et al. (2011), plasma concentrations of cortisol higher than $34.1 \mathrm{nmol} / \mathrm{L}$ (corresponding to $1.23 \mu \mathrm{g} / \mathrm{dL}$ ) in dairy cattle during the last two weeks of prepartum lead to a greater chance of metabolic disorders.

Figure 2. Average values of hormonal parameters of Holstein cows in the transition period as a function of lactating weeks in females from MTVG (- - ) or CG (-).

a)

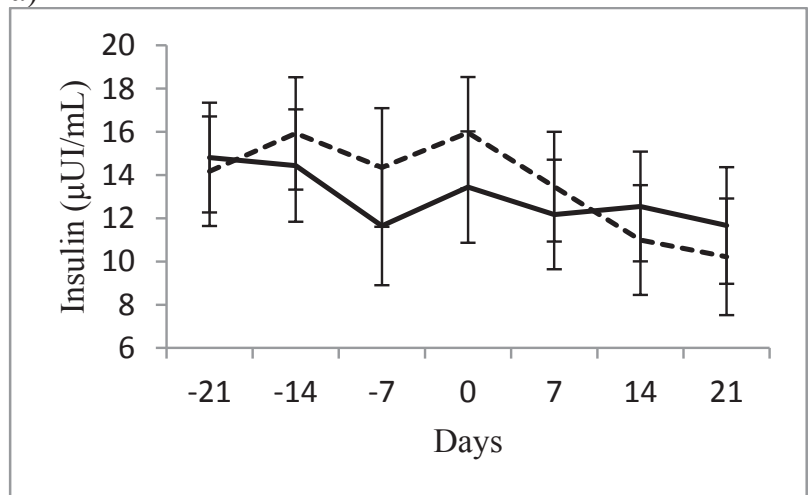

b)

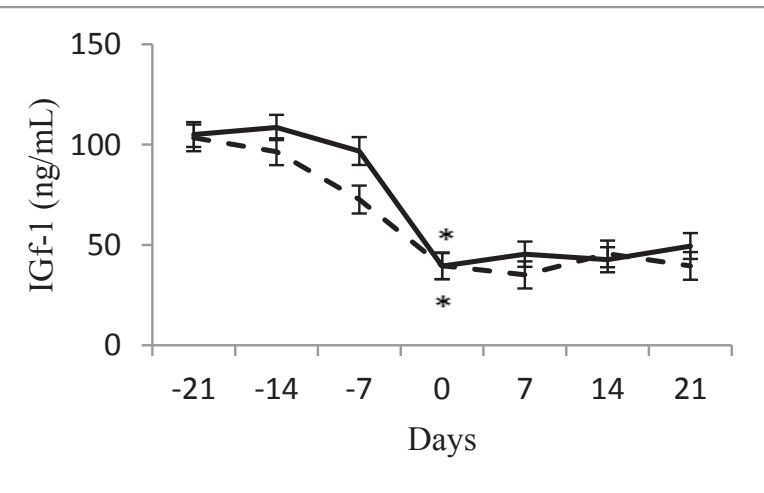

c)

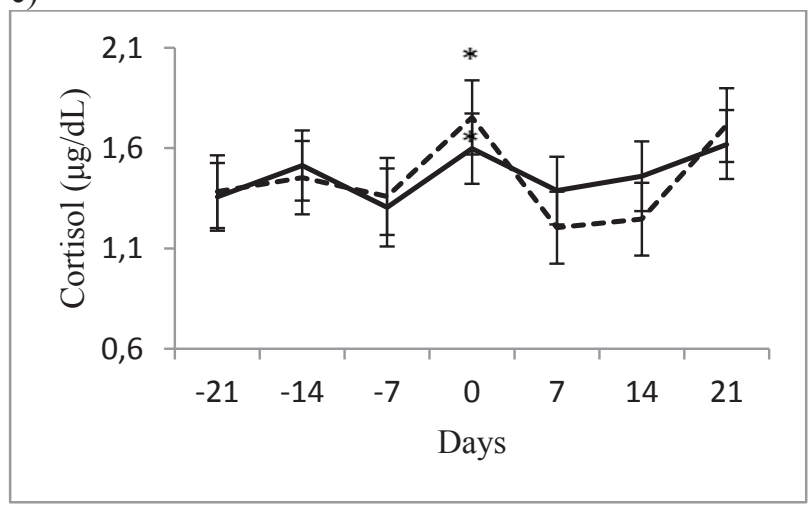

a) Insulin $(\mu \mathrm{UI} / \mathrm{mL})$; b) IGF-1 $(\mathrm{ng} / \mathrm{mL})$; c) Cortisol $(\mu \mathrm{g} / \mathrm{dL})$. The error bar represents the standard error of the mean. *Significant effect of day. 
Cortisol is the hormone that suppresses the immune response by causing down-regulation of L-selectin and $\beta 2$-integrin expression (CD18) by neutrophils, adhesion molecules involved in neutrophil trafficking from the endothelium to the site of infection (BURTON et al., 2005). In our study, animals from MTVG presented high cortisol values at parturition, but decreased significantly during the first week of lactation, differently of the animals from CG. This fact may be directly related to the use of trace minerals and vitamins $\mathrm{A}$ and $\mathrm{E}$. These elements were able to modulate the immune response in females of MTVG, but it is not possible to state if this relationship is also involved with cortisol.

Thus, no influence of the use of trace minerals and vitamins $\mathrm{A}$ and $\mathrm{E}$ was observed on the metabolic and hormonal parameters in dairy cows in the transition period. However, some important biochemical and hormonal parameters are altered on the parturition day, even in animals with a good nutritional status.

\section{Acknowledgments}

To UNOESC (call No. 20/ UNOESC-R/ 2015) and CAPES for the financial support.

\section{References}

ALVES, N. G.; PEREIRA, M. N.; COELHO, R. M. Nutrição e reprodução em vacas leiteiras. Revista Brasileira de Reprodução Animal, Belo Horizonte, v. 6, p. 118-124, 2009.

AVCI, C.; KIZIL, O. The effects of injectable trace elements on metabolic parameters in transition cow. Kafkas Üniversitesi Veteriner Fakültesi Dergisi, Kars, v. 19, p. A73-A78, 2013. Supplement A.

BELL, A. W. Regulation of organic nutrient metabolism during transition from late pregnancy to early lactation. Journal of Animal Science, Champaign, v. 73, n. 9, p. 2804-2819, 1995.

BURTON, J. L.; MADSEN, S.; CHANG, L. C.; WEBER, P. S.; BUCKMAN, K. R.; VAN DORP, R.; HICKEY,
M. C.; EARLEY, B. Gene expression signatures in neutrophils exposed to glucocorticoids: a new paradigm to help explain neutrophil dysfunction in parturient dairy cows. Veterinary Immunology and Immunopathology, Amsterdam, v. 105, n. 3-4, p. 197-219, 2005.

CEBALlOS, A.; VILLA, N. A.; BOHÓRQUEZ, A.; QUICENO, J.; JARAMILLO, M.; GIRALDO, G. Análisis de los resultados de perfiles metabólicos en lecherías del trópico alto del eje cafetero colombiano. Revista Colombiana Ciências Pecuária, Medellín, v. 151, n. 1, p. 26-35, 2002.

CHAPINAL, N.; CARSON, M.; DUFFIELD, T. F.; CAPEL, M.; GODDEN, S.; OVERTON, M.; SANTOS, J. E.; LEBLANC, S. J. The association of serum metabolites with clinical disease during the transition period. Journal of Dairy Science, Champaign, v. 94, n. 10, p. 4897-4903, 2011.

CUNNINGHAM, J. G. Tratado de fisiologia veterinária. Rio de Janeiro: Guanabara Koogan, 2004. 579 p.

CUPERTINO, C.F.; PEREIRANETO, E.; BARCELLOS, M. P.; SENA, F. P.; LENZ, D.; BARIONI, G. Avaliação do perfil metabólico em vacas leiteiras de alta produção no período de transição. PUBVET, Londrina, v. 5, n. 18 , p. 1112-1117, 2011.

EDMONSON, A. J.; LEAN, I. J.; WEAVER, L. D.; FARVER, T.; WEBSTER, G. A body condition scoring chat for Holstein dairy cows. Journal of Dairy Science, Champaign, v. 72, n. 1, p. 68-78, 1989.

FOSBERG, N. Recent insights into ruminant immune function: effects of stress and of immunostimulatory feed products. In: FLORIDA RUMINANT NUTRITION SYMPOSIUM, 2004, Florida. Proceedings... Florida, 2004. p. 81-92.

FOULADI-NASHTA, A. A.; CAMPBELL, K. H. $\mathrm{S}$. Dissociation of oocyte nuclear and cytoplasmic maturation by the addition of insulin in cultured bovine antral follicles. Reproduction, Bristol, v. 31, n. 3, p. 449460. 2006.

GOFF, J. P. The monitoring, prevention, and treatment of milk fever and subclinical hypocalcemia in dairy cows. The Veterinary Journal, London, v. 176, n. 1, p. 50-57, 2008.

GREGORY,L.; BIRGELJUNIOR, E.H.; D`ANGELINO, J. L.; BENESI, F. J.; ARAÚJO, W. P.; BIRGEL, E. H. Valores de referência dos teores da uréia e creatinina em bovinos da raça Jersey criados no Estado de São Paulo. Influência dos fatores etários, sexuais e da infecção pelo vírus da leucose dos bovinos. Arquivo Instituto Biológico, São Paulo, v. 71, n. 3, p. 339-345, 2004. 
HAYIRLI, A.; HAYIRLI, A.; GRUMMER, R. R.; NORDHEIM, E. V.; CRUMP, P. M. Animal and dietary factors affecting feed intake during the prefresh transition period in Holsteins. Journal of Dairy Science, Champaign, v. 85, n. 12, p. 3430-3443, 2002.

HERDT, T. H. Ruminant adaptation to negative energy balance: influences on the etiology of ketosis and fatty liver. Veterinary Clinics of North America: Food Animal Practice, London, v. 16, n. 2, p. 215-230, 2000.

HUZZEY, J. M.; NYDAM, D. V.; GRANT, R. J.; OVERTON, T. R. Associations of prepartum plasma cortisol, haptoglobin, fecal cortisol metabolites, and nonesterified fatty acids with postpartum health status in Holstein dairy cows. Journal of Dairy Science, Champaign, v. 94, n. 12, p. 5878-5889, 2011.

INGVARTSEN, K. L.; MOYES, K. Nutrition, immune function and health of dairy cattle. Animal Journal, Cambridge, v. 7, n. 1, p. 112-122, 2012.

JENSEN, A.; PETERSEN, M. B.; HOUE, H. Determination of the fructosamine concentration in bovine serum samples. Journal of Veterinary Medicine, London, v. A, n. 40, p. 111-117, 1993.

KHATTI, A.; MEHROTRA, S.; PATEL, P. K.; SINGH, G.; MAURYA, V. P.; MAHLA, A. S.; CHAUDHARI, R. K.; DAS, G. K.; SINGH, M.; SARKAR, M.; KUMAR, H.; KRISHNASWAMY, N. Supplementation of vitamin $\mathrm{E}$, selenium and increased energy allowance mitigates the transition stress and improves postpartum reproductive performance in the crossbred cow. Theriogenology, Stoneham, v. 104, n. 1, p. 142-148, 2017.

KUNZ, P. L.; BLUM, J. W.; HART, I. C.; BICKEL, H.; LANDIS, J. Effects of different energy intakes before and after calving on food-intake, performance and blood hormones and metabolites in dairy cows. Animal Production, Midlothian, v. 40, n. 2, p. 219-231, 1985.

LEAN, I. J.; SAUN, R. V.; DEGARIS, J. P. Energy and protein nutrition management of transition dairy cows. Veterinary Clinics of North America: Food Animal Practice, London, v. 29, n. 2, p. 337-366, 2013.

LEBLANC, S. J.; LESLIE, K. E.; DUFFIELD, T. F. Metabolic predictors of displaced abomasum in dairy cattle. Journal of Animal Science, Champaign, v. 88, n. 1, p. 159-170, 2005.

LÓPEZ, S. E.; LÓPEZ, J.; STUMPF JUNIOR, E. W. Parâmetros séricos de vacas leiteiras na fase inicial de lactação suplementadas com diferentes fontes de gordura. Archivos Latinoamericanos de Producción Animal, Mayaguez, v. 12, n. 3, p. 96-102, 2004.
LUCY, M. C. Functional differences in the growth hormone and insulin-like growth factor axis in cattle and pigs: implications for post-partum nutrition and reproduction. Reproduction in Domestic Animals, v. 43, p. 31-39, 2008. Supplement 2.

MACHADO, V. S.; OIKONOMOU, G.; LIMA, S. F.; BICALHO, M. L. S.; KACAR, C.; FODITSCH, C.; FELIPPE, M. J.; GILBERT, R. O.; BICALHO, R. C. The effect of injectable trace minerals (selenium, copper, zinc, and manganese) on peripheral blood leukocyte activity and serum superoxide dismutase activity of lactating Holstein cows. The Veterinary Journal, London, v. 200, n. 2, p. 299-304, 2014.

MECITOĞLU, Z.; ÇETIN KASAP, S.; ÖZDÜVEN, M. L.; ÖZDER, M.; ENNERMAN, E. Effects of prepartum treatment with monensin or propylene glycol mixed with concentrate on milk yield and blood NEFA and BHBA levels in dairy cows. Turkish Journal of Veterinary and Animal Sciences, Ankara, v. 41, n. 1, p. 667-671, 2017.

MOORBY, J. M.; DEWHURST, R. J.; TWEED, J. K. S.; DHANOA, M. S.; BECK, N. F. G. Effects of altering the energy and protein supply to dairy cows during the dry period. 2. Metabolic and hormonal responses. Journal of Dairy Science, Champaign, v. 83, n. 8, p. 1795-1805, 2000.

NATIONAL RESEARCH COUNCIL - NRC. Nutrient requirements of dairy cattle. $7^{\text {th }}$ ed. Washington: National Academies Press, 2001. 381 p.

NIKOLIC, J. A.; KULCSÁR, M.; KÁTAI, L.; NEDIĆ, O.; JÁNOSI, S.; HUSZENICZA, G. Periparturient endocrine and metabolic changes in health cows and in cows affected by mastitis. Journal Veterinary Medicine, London, v. 50, n. 1, p. 22-29, 2003.

OMUR, A.; KIRBAS, A.; AKSU, E.; KANDEMIR, F.; DORMAN, E.; KAYNAR, O.; UCAR, O. Effects of antioxidant vitamins (A, D, E) and trace elements $(\mathrm{Cu}$, $\mathrm{Mn}, \mathrm{Se}, \mathrm{Zn}$ ) on some metabolic and reproductive profiles in dairy cows during transition period. Polish Journal of Veterinary Sciences, Olsztyn, v. 19, n. 4, p. 697-706, 2016.

ORTOLANI, E. L. Aspectos clinicos, epidemiologicos e terapeuticos da hipocalcemia de vacas leiteiras. Arquivos Brasileiros de Medicina Veterinária e Zootecnia, Belo Horizonte, v. 47, n. 6, p. 799-808, 1995.

OSPINA, P. A.; NYDAM, D. V.; STOKOL, T.; OVERTON, T. R. Evaluation of nonesterified fatty acids and $\beta$-hydroxybutyrate in transition dairy cattle in the northeastern United States: critical thresholds for prediction of clinical diseases. Journal of Dairy Science, Champaign, v. 93, n. 2, p. 546-554, 2010. 
PETTERSON, J. A.; DUNSHEA, F. R.; EHRHARDT, R. A.; BELL, A. W. Pregnancy and undernutrition alter glucose metabolic responses to insulin in sheep. The Journal of Nutrition, Bethesda, v. 123, n. 7, p. 12861295, 1993.

PICKETT, M. M.; PIEPENBRINK, M. S.; OVERTON, T. R. Effects of propylene glycol or fat drench on plasma metabolites, liver composition, and production of dairy cows during the periparturient period. Journal of Dairy Science, Champaign, v. 86, n. 6, p. 2113-2121, 2003.

PUTMAN, A. K.; BROWN, J. L.; GANDY, J. C.; WISNIESKI, L.; SORDILLO, L. M. Changes in biomarkers of nutrient metabolism, inflammation, and oxidative stress in dairy cows during the transition into the early dry period. Journal of Dairy Science, Champaign, v. 101, n. 10, p. 9350-9359, 2018.

RAMOS, J. M.; SOSA, C.; RUPRECHTER, G.; PESSINA, P.; CARRIQUIRY, M. Effect of organic trace minerals supplementation during early postpartum on milk composition, and metabolic and hormonal profiles in grazing dairy heifers. Spanish Journal of Agricultural Research, Madrid, v. 10, n. 3, p. 681-689, 2012.

SILVA FILHO, A. P.; MENDONÇA, C. L.; SOUTO, R. J. C.; SILVA, R. J.; SOARES, P. C.; AFONSO, J. A. B. Indicadores bioquímico e hormonal de vacas leiteiras mestiças sadias e doentes durante o final da gestação e o início da lactação. Pesquisa Veterinária Brasileira, Seropédica, v. 37, n. 11, p. 1229-1240, 2017.
SMITH, T. R.; HIPPEN, A. R.; BEITZ, D. C.; YOUNG, J. W. Metabolic characteristics of induced ketosis in normal and obese dairy cows. Journal of Animal Science, Champaign, v. 80, n. 8, p. 1569-1581, 1997.

SORDILLO, L. M.; AITKEN, S. L. Impact of oxidative stress on the health and immune function of dairy cattle. Veterinary Immunology and Immunopathology, Amsterdam, v. 128, n. 1-3, p. 104-109, 2009.

SORDILLO, L. M.; RAPHAEL, W. Significance of metabolic stress, lipid mobilization, and inflammation on transition cow disorders. Veterinary Clinics of North America: Food and Practice, London, v. 29, n. 2, p. $267-$ 278, 2013.

SPICER, L. J.; TUCKER, W. B.; ADAMS, G. D. Insulinlike growth factor-I in dairy cows: relationships among energy balance, body condition, ovarian activity, and estrous behavior. Journal of Animal Science, Champaign, v. 73, n. 4, p. 929-937, 1990.

THRALL, M. A. Hematologia e bioquímica clínica veterinária. São Paulo: Roca, 2007. 582 p.

XIN, Z.; WATERMAN, D. F.; HEMKEN, R.W.; HARMON, R. J. Copper status and requirement during the dry period and early lactation in multiparous Holstein cows. Journal of Animal Science, Champaign, v. 76, p. 2711-2716, 1993. 